\title{
EVALUATION OF CREEP STRENGTH OF HETEROGENEOUS WELDED JOINT IN HR6W ALLOY AND SANICRO 25 STEEL
}

\begin{abstract}
This article presents the results of investigations on HR6W alloy and Sanicro 25 steel and the dissimilar welded joint made of them. The characteristic images of microstructure of the investigated materials in the as-received condition and following the creep test, observed with a scanning electron microscope (SEM), are shown. The X-ray analysis of phase composition of the existing precipitates was carried out. The method for evaluation of creep strength based on abridged creep tests carried out at a temperature higher than the design one is presented. The obtained results do not deviate from the values of creep strength determined in longterm creep tests. The maximum difference in creep strength of the investigated materials is $\pm 20 \%$, which is in compliance with the acceptable scatter band. The methodology presented can be used for verification of creep strength (life time) of the material of finished components to be operated under creep conditions.

Keywords: creep test, HR6W alloy, Sanicro 25 steel, microstructure
\end{abstract}

\section{Introduction}

The energy demand in Poland makes the investments in the energy sector, understood as the construction of new units and modernisation of those under operation, become necessary. At present, the construction of boilers with supercritical working parameters with efficiency of above $46 \%$ and total capacity of above $6000 \mathrm{MW}$ is being realised in Poland. The units such as 1075 MW in Kozienice, 450 MW in Turow and two units of $900 \mathrm{MW}$ in Opole and the extension of Jaworzno III Power Plant with the unit of $910 \mathrm{MW}$ are to meet the energy demand for the coming years.

The electricity generation in Poland is still based on coal and lignite, and their considerable resources are the primary source of energy $[1,2]$. However, it is associated with adverse emission of significant pollutants into the atmosphere as carbon dioxide $\left(\mathrm{CO}_{2}\right)$, sulphur dioxide $\left(\mathrm{SO}_{2}\right)$, nitrogen oxide $\left(\mathrm{NO}_{\mathrm{x}}\right)$ and different types of dusts. The pollutant reduction may be achieved by the enhancement in steam parameters. This affects boiler efficiency and economy - lower consumption of coal. To face up to much higher steam temperature in boilers with supercritical and ultra-supercritical parameters, especially at the final degrees of superheat, the austenitic steels or nickel alloys, which undoubtedly include the Sanicro 25 steel and HR6W alloy, are used. They are characterised by sufficiently high creep strength combined with high resistance to high-temperature corrosion in the atmosphere of combustion gases and resistance to oxidation in steam $[3,4]$.

Sanicro 25 is a high-alloy austenitic steel designed for the new generation of power boilers with supercritical and ultrasupercritical working parameters. It is characterised by high strength properties at elevated temperature and very high creep resistance $\left(R_{z / 100,000 / 700)}=95 \mathrm{MPa}\right)$. It is distinguished by good stability of the microstructure. It is used for structural elements working at up to $750^{\circ} \mathrm{C}$. The Sanicro 25 steel creep strength is summarised in Table 1.

TABLE 1

Creep rupture strength of Sanicro 25 steel acc. VdTÜV555, 09.2008

\begin{tabular}{|c|c|c|c|c|c|c|c|c|}
\hline \hline Temperature $\left[{ }^{\circ} \mathbf{C}\right]$ & $\mathbf{5 0 0}$ & $\mathbf{5 5 0}$ & $\mathbf{6 0 0}$ & $\mathbf{6 5 0}$ & $\mathbf{7 0 0}$ & $\mathbf{7 5 0}$ & $\mathbf{8 0 0}$ \\
\hline & \multicolumn{8}{|c|}{ Creep strength [MPa] } \\
\hline $10,000 \mathrm{~h}$ & 500 & 380 & 310 & 230 & 145 & 85 & 50 \\
\hline $100,000 \mathrm{~h}$ & 405 & 325 & 230 & 155 & 95 & 50 & 25 \\
\hline
\end{tabular}

HR6W alloy was developed in Japan in the end of 1980s as a material for production of high-strength tubes for construction of USC boilers with steam temperature above $650^{\circ} \mathrm{C}$. It is an alloy with high nickel content (43\%) and austenitic microstructure. It is distinguished by high stability of the structure when working under creep conditions. It shows high creep strength $\left(\mathrm{R}_{\mathrm{Z} / 100000 / 700}=85 \mathrm{MPa}\right)$. The HR6W alloy creep strength is summarised in Table 2. 
TABLE 2

Creep rupture strength of HR6W alloy acc. Vd TUV 559/2 09.2011

\begin{tabular}{|c|c|c|c|c|c|}
\hline \hline Temperature $\left[{ }^{\circ} \mathbf{C}\right]$ & $\mathbf{6 0 0}$ & $\mathbf{6 5 0}$ & $\mathbf{7 0 0}$ & $\mathbf{7 5 0}$ & $\mathbf{8 0 0}$ \\
\hline & \multicolumn{6}{|c|}{ Creep strength $[\mathrm{MPa}]$} \\
\hline $10,000 \mathrm{~h}$ & 204 & 145 & 106 & 76 & 51 \\
\hline $100,000 \mathrm{~h}$ & 169 & 118 & 85 & 62 & 42 \\
\hline
\end{tabular}

In the assessment of the life time of steels and alloys working under creep conditions, the main source of information is still creep tests in spite of the fact that their disadvantage is significant time to obtain test results [5-10]. To reduce the duration of testing and assessment of the life time, the so-called abridged creep tests with duration from a few dozen to max 10 to 15 thousand hours are used in practice [11]. This offers the possibility to obtain test results within a maximum of several months.

The acceleration of the creep process and reduction in duration of testing is obtained by conducting tests at a constant test stress corresponding to the operating one and different test temperatures higher than the operating one.

The results of the abridged creep tests conducted at a constant stress equal to the service one and in long-term creep tests as part of own research carried out at the Institute for Ferrous Metallurgy verified this method positively, which allowed its use in the engineering practice for the steels for critical components of the pressure part of boilers [2]. Fig. 1 presents the graphic method for determination of the life time using the abridged creep tests.

The estimation of the life time by abridged creep tests is performed for both the materials in the as-received condition, by determining service life for the assumed parameters of the expected service, and the materials after service, by determining the so-called disposable residual life, which is the time of safe operation under the assumed temperature and stress conditions of further service (Fig. 2) [2,6].

\section{Research material}

The material for investigations included the tubes of $45 \times 8.8$ $\mathrm{mm}$ for steam superheater coils, welded automatically by the 141 Aut method. Chemical composition of the investigated steels with regard to the requirements of relevant standards are summarised in Table 3 for HR6W alloy and in Table 4 for Sanicro 25 steel. Specimens for creep tests were made out of the dissimilar welded joints made of these materials (Fig. 3).

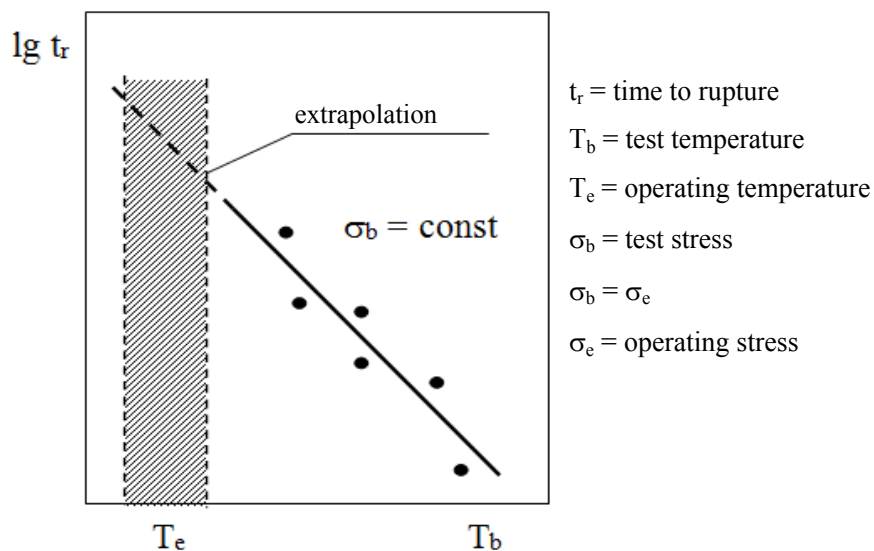

Fig. 1. The method for residual life-time assessment based on abridged creep tests

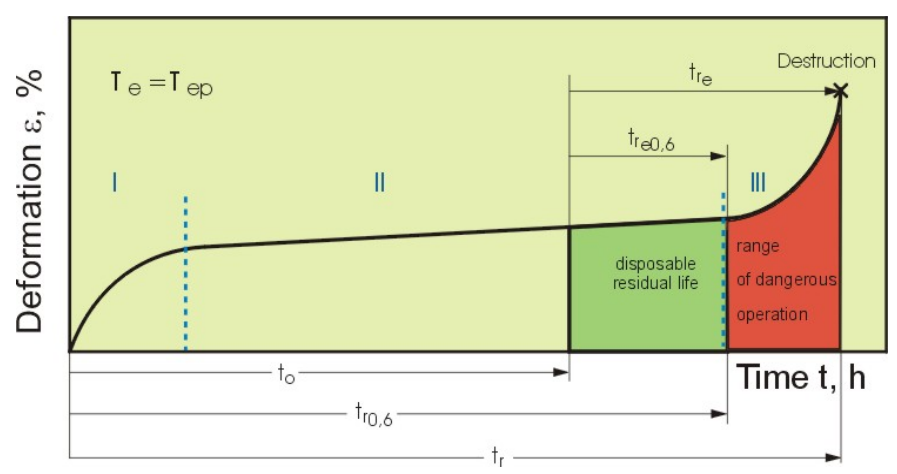

Fig. 2. Definition of available durability $\operatorname{tr}_{\mathrm{e} 0,6}$ and residual life determination $\operatorname{tr}_{\mathrm{e}}[2]$

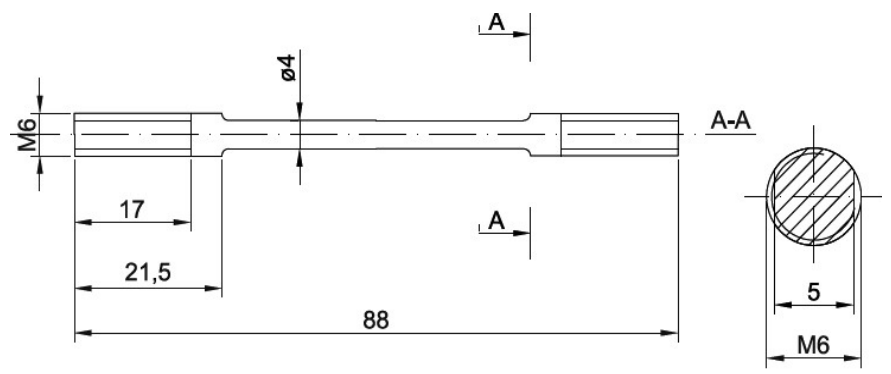

Fig. 3. Diagram of specimen for abridged creep tests

\section{Methodology}

The investigations of microstructure were carried out with Inspect $\mathrm{F}$ scanning electron microscope on metallographic crosssections etched with Mi19Fe reagent.

TABLE 3

Chemical composition of the investigated HR6W alloy with regard to the requirements of relevant standards

\begin{tabular}{|c|c|c|c|c|c|c|c|c|c|c|c|}
\hline \multirow{2}{*}{ No. } & \multicolumn{11}{|c|}{ Chemical composition wt\% } \\
\hline & $\mathbf{C}$ & Mn & $\mathbf{P}$ & $\mathrm{S}$ & $\mathbf{S i}$ & $\mathrm{Cr}$ & Fe & $\mathbf{T i}$ & $\mathbf{W}$ & $\mathbf{N b}$ & $\mathbf{N i}$ \\
\hline Test material & 0.08 & 1.15 & 0.008 & 0.008 & 0.20 & 22.81 & 22.0 & 0.11 & 8.0 & 0.19 & 45.69 \\
\hline $\begin{array}{c}\text { Vd } \\
\text { TÜV 559/2 }\end{array}$ & $\begin{array}{c}\max \\
0.105\end{array}$ & $\begin{array}{l}\max \\
1.54\end{array}$ & $\begin{array}{c}\max \\
0.033\end{array}$ & $\begin{array}{c}\max \\
0.018\end{array}$ & $\begin{array}{l}\max \\
1.05\end{array}$ & $\begin{array}{l}21.25- \\
24.75\end{array}$ & $\begin{array}{l}16.65- \\
30.35\end{array}$ & $\begin{array}{l}\max \\
0.25\end{array}$ & $\begin{array}{c}0.80- \\
1.20\end{array}$ & $\begin{array}{l}\max \\
0.35\end{array}$ & remainder \\
\hline
\end{tabular}


Chemical composition of the investigated Sanicro 25 steel with regard to the requirements of relevant standards

\begin{tabular}{|c|c|c|c|c|c|c|c|c|c|c|c|c|c|c|}
\hline \hline \multirow{2}{*}{ No. } & \multicolumn{10}{|c|}{ Chemical composition wt\% } \\
\cline { 2 - 15 } & $\mathbf{C}$ & $\mathbf{M n}$ & $\mathbf{P}$ & $\mathbf{S}$ & $\mathbf{S i}$ & $\mathbf{C r}$ & $\mathbf{C o}$ & $\mathbf{C u}$ & $\mathbf{W}$ & $\mathbf{N b}$ & $\mathbf{N i}$ & $\mathbf{N}$ & $\mathbf{B}$ & $\mathbf{F e}$ \\
\hline Test material & 0.064 & 0.51 & 0.016 & 0.0005 & 0.18 & 22.35 & 1.44 & 2.98 & 3.37 & 0.49 & 25.31 & 0.23 & 0.0035 & Balance \\
\hline VD-TÜV 555 & 0.03 & $\max$ & $\max$ & $\max$ & $\max$ & $\begin{array}{c}21.50- \\
23.50\end{array}$ & $1.0-2.0$ & $2.0-3.5$ & $2.0-4.0$ & $0.3-0.6$ & $\begin{array}{c}23.50- \\
26.50\end{array}$ & $\begin{array}{c}0.15- \\
0.30\end{array}$ & $\begin{array}{c}\mathrm{max} \\
0.008\end{array}$ & Balance \\
\hline
\end{tabular}

Phase composition of the precipitates was determined by the carbide isolate method with PANalytical Empyrean X-ray diffractometer by using filtered cobalt radiation in configuration with Pixcel detector. The precipitate isolation was carried out in $5 \%$ aqueous solution of hydrochloric acid, at current density of $10 \mathrm{~mA} / \mathrm{cm}^{2}$. The duration of isolation was 48 hours. The isolate was cleaned by repeated rinsing in distilled water and ethyl alcohol. After each rinse, the isolate was centrifuged. The last stage was drying the isolate at $45^{\circ} \mathrm{C}$ for $24 \mathrm{~h}$. Hardness measurement was taken by Vickers method with the indenter load of $10 \mathrm{~kg}(98.1 \mathrm{~N})$.

Creep tests of the investigated steels and their welded joint were carried out without elongation measurement during test. The tension creep-testing machine by Instron, model M3TCS, which ensures constant temperature of $\pm 0.5^{\circ} \mathrm{C}$ at a test temperature of up to $800^{\circ} \mathrm{C}$, was used during testing with PLC (Programmable Logic Controller). Temperature control and measurements were carried out using three S-type sheathed thermocouples in class 1 arranged over the gauge length of the test piece. Creep tests were carried out at $650,675,700,725$ and $750^{\circ} \mathrm{C}$ and $200 \mathrm{MPa}$.

The crucial element of the above-mentioned tests is the method for determination of creep strength. This determination is based on creep test results. In creep tests, the decisive factor for their duration is the time to rupture. It cannot be reduced when developing the material characteristics. However, there is such a possibility in the assessment of specific material both in the as-received condition and after service. The research methods used for this purpose were verified with the results of long-term creep tests $[2,4,11]$.

\section{Results of research and their discussion}

\subsection{Microstructure}

The microstructure of the investigated dissimilar welded joint, including HR6W alloy and Sanicro 25 steel parent material, the heat affected zone and the weld material, observed with a scanning electron microscope, is shown in Fig. 4.

In the as-received condition, HR6W alloy is characterised by austenitic microstructure with a slight amount of $(\mathrm{Ti}, \mathrm{Nb}) \mathrm{C}$ and $\mathrm{M}_{23} \mathrm{C}_{6}$ primary precipitates (Fig. 4a, Table 5). In addition to the primary precipitates, the continuous grid of precipitates at the grain boundaries was observed within the heat affected zone of HR6W alloy (Fig. 4b).
Similarly to HR6W alloy, Sanicro 25 steel in the as-received condition has an austenitic microstructure with niobium and titanium-rich precipitates and $\mathrm{M}_{23} \mathrm{C}_{6}$ precipitates containing mainly chromium (Fig. 4c). In the X-ray phase composition analysis, a copper-rich phase $\varepsilon_{-} \mathrm{Cu}$ was also identified in Sanicro 25 steel (Table 5).

Insignificant local growth in the size of grains with a slightly intensified precipitation of secondary phases was observed within the heat affected zone of Sanicro 25 steel (Fig. 4d). The microstructure of the weld, made with Thermanit 617, is shown in Fig. 4e,f where dendritic/cellular and dendritic/columnar microstructure was observed [3].

TABLE 5

Results of X-ray phase analysis of isolates in the investigated materials in the as-received condition.

\begin{tabular}{|c|c|}
\hline$\stackrel{\text { Grade }}{\text { material condition }}$ & Phase composition \\
\hline $\begin{array}{l}\underline{\mathrm{HR} 6 \mathrm{~W}} \\
\text { as-received }\end{array}$ & $\begin{array}{c}\mathrm{M}_{23} \mathrm{C}_{6} \text { containing mainly } \mathrm{Cr} \\
\mathrm{Ti}_{0.5} \mathrm{Nb}_{0.5} \mathrm{C}\end{array}$ \\
\hline$\frac{\text { Sanicro } 25}{\text { as-received }}$ & $\begin{array}{c}\mathrm{M}_{23} \mathrm{C}_{6} \text { containing mainly } \mathrm{Cr} \\
\mathrm{NbCrN} \\
\mathrm{Ti}_{0.5} \mathrm{Nb}_{0.5} \mathrm{C} \\
\mathrm{TiN} \\
\varepsilon \mathrm{Cu} \text { (may contain } \mathrm{Fe}, \mathrm{Cr}, \mathrm{Ni})\end{array}$ \\
\hline
\end{tabular}

Long-term exposure to elevated temperature and applied stress had significant impact on microstructure of the investigated materials, which differs significantly from the as-received condition (Fig. 4). It was revealed that creep conditions intensified the secondary phase precipitation processes in Sanicro 25 steel and HR6W alloy.

In the microstructure of HR6W alloy, the evenly distributed fine $\mathrm{M}_{23} \mathrm{C}_{6}$ carbide precipitates and single primary $\mathrm{MX}$ precipitates of large size were observed inside the austenite grains (Fig. 5 Table 5), while at the grain boundaries the increase in the quantity and size of $\mathrm{M}_{23} \mathrm{C}_{6}$ precipitates and $\mathrm{Fe}_{2} \mathrm{~W}$ intermetallic Laves phase precipitates was observed (Fig. 5, Table 5). The origins of the Laves phase precipitates were also observed inside the grains as irregularly shaped elongated particles [3]. Similar results of identification tests of precipitates existing in HR6W alloy after creep test, in relation to thermodynamic calculations, are presented in [12].

As in the case of HR6W alloy, after creeping $\left(675^{\circ} \mathrm{C} / 200\right.$ $\mathrm{MPa} / 675 \mathrm{~h}$ ) the evenly distributed fine $\mathrm{M}_{23} \mathrm{C}_{6}$ precipitates and 

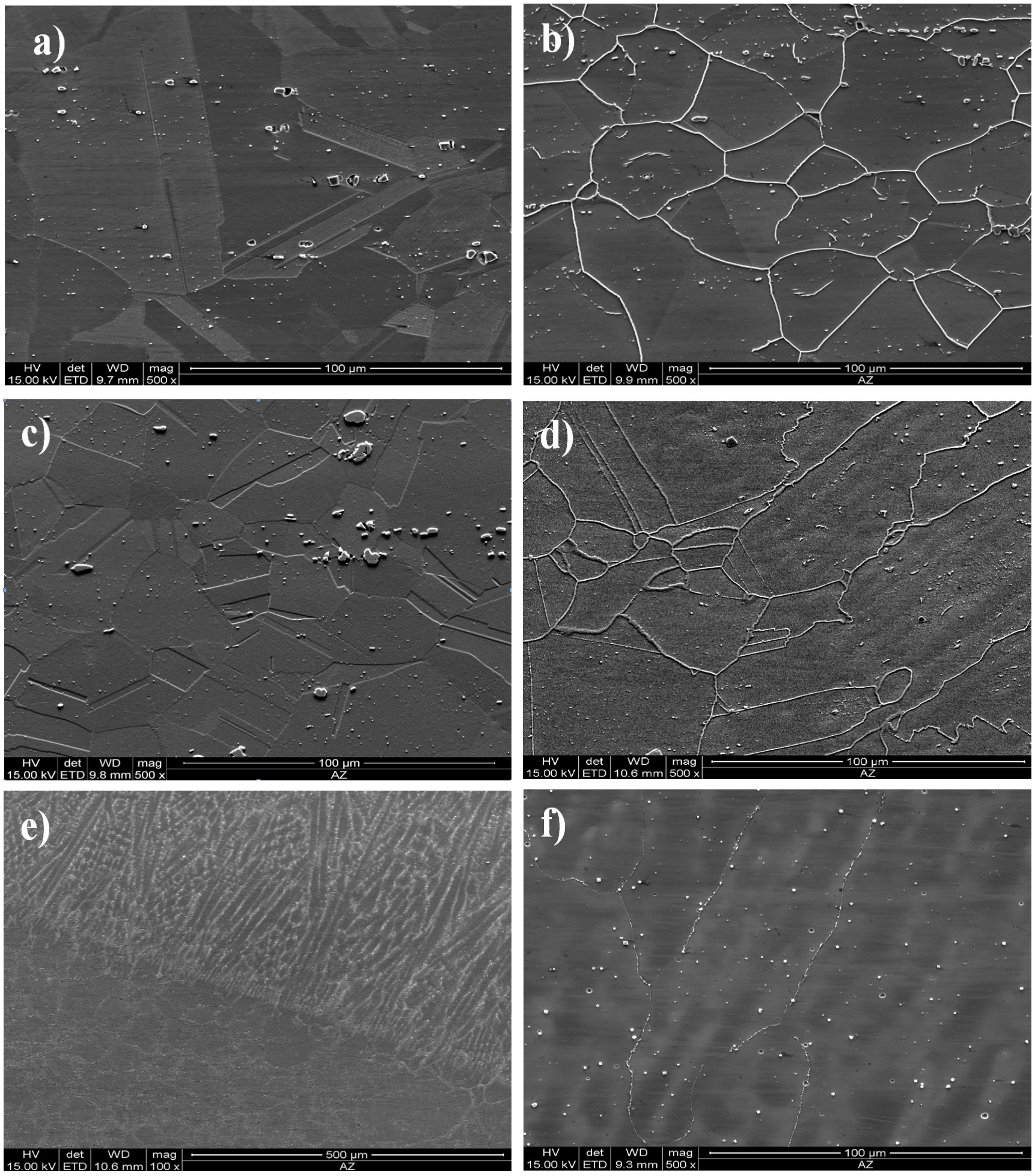

Fig. 4. Microstructure of dissimilar welded joint elements a) HR6W parent material, b) HR6W HAZ, c) Sanicro 25 parent material, d) Sanicro $25 \mathrm{HAZ}$, e) Sanicro $25 \mathrm{HAZ} /$ weld, f) weld, SEM observation

TABLE 5

Microanalysis of chemical composition of precipitates in HR6W alloy after creep test carried out using scanning electron microscope with EDS detector

\begin{tabular}{|c|c|c|c|c|c|c|c|c|c|}
\hline \hline Element, wt\% & $\mathbf{C}$ & $\mathbf{N}$ & $\mathbf{W}$ & $\mathbf{N b}$ & $\mathbf{T i}$ & $\mathbf{C r}$ & $\mathbf{M n}$ & $\mathbf{N i}$ & $\mathbf{F e}$ \\
\hline $\mathrm{MX}$ & 8.07 & 7.89 & 8.11 & 13.08 & 53.73 & 4.31 & - & 4.82 & \\
\hline $\mathrm{M}_{23} \mathrm{C}_{6}$, at the grain boundary & 7.62 & - & 21.28 & - & - & 55.72 & - & 3.20 & 12.08 \\
\hline $\mathrm{M}_{23} \mathrm{C}_{6}$, inside the grain & 6,52 & - & 26,29 & - & - & 50,80 & - & 5,73 & 10,61 \\
\hline Laves phase & 3.48 & - & 60.25 & 0.22 & - & 16.31 & - & 5.23 & 14.50 \\
\hline
\end{tabular}



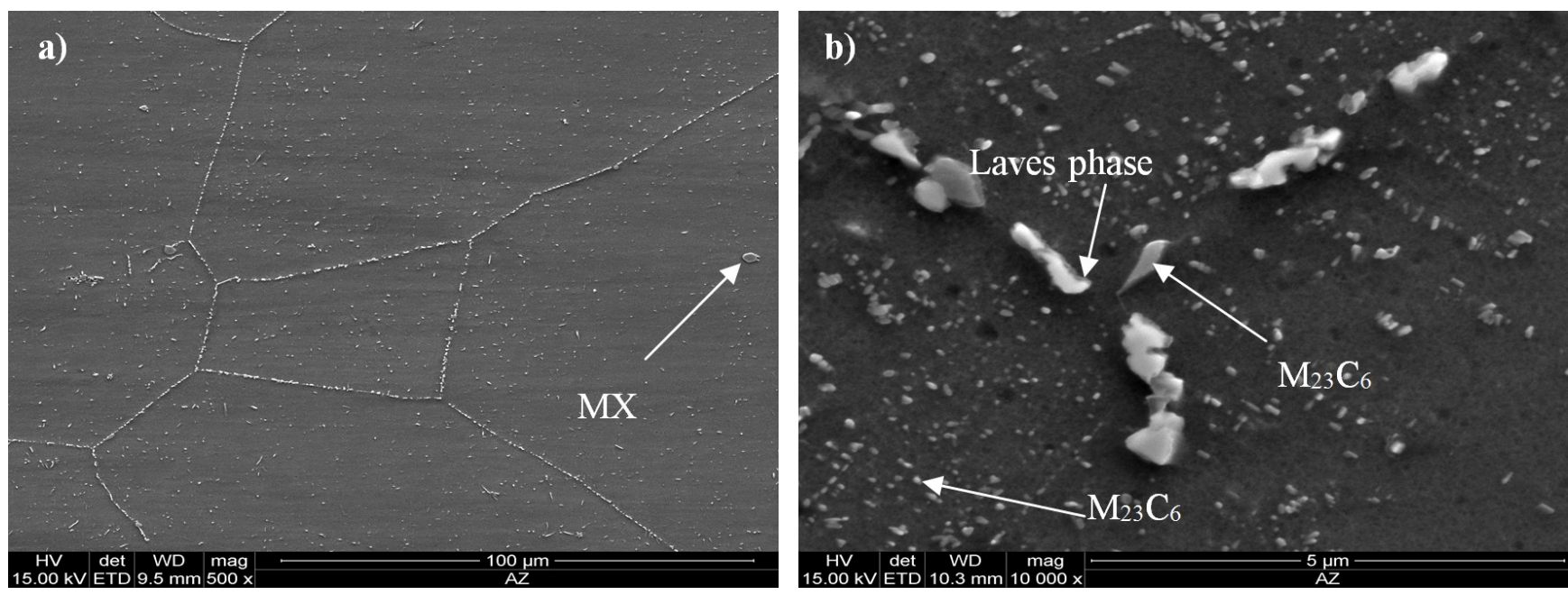

Fig. 5. Microstructure of HR6W alloy after long-term exposure to temperature and stress $\left(675^{\circ} \mathrm{C} / 200 \mathrm{MPa} / 675 \mathrm{~h}\right)$

single primary MX precipitates were observed in the microstructure of Sanicro 25 steel inside the grains (Fig. 6, Table 6). At the grain boundaries, chromium-rich $\mathrm{M}_{23} \mathrm{C}_{6}$ precipitates were observed, while inside the grains there were tungsten-rich $\mathrm{M}_{23} \mathrm{C}_{6}$ precipitates (Fig. 6, Table 6). The example of surface distribution of chromium and tungsten for Sanicro 25 steel after $700{ }^{\circ} \mathrm{C} / 200$ $\mathrm{MPa} / 675 \mathrm{~h}$ creeping is shown in Fig. 7.

The X-ray phase analysis of particles in the investigated materials after creep test by isolate method showed that in addition to identified $\mathrm{MX}$ and $\mathrm{M}_{23} \mathrm{C}_{6}$ precipitates there were also $\mathrm{NbCrN}$ precipitates in Sanicro 25 steel (Fig. 8).
In contrast to $9 \div 12 \% \mathrm{Cr}$ martensitic steels, the $\mathrm{NbCrN}$ precipitates $-\mathrm{Z}$ phase in austenitic steels are favourable precipitates, which have significant impact on the increase in strengthening of these steels with the precipitation mechanism. It contributes to the enhancement in strength properties, hardness and creep resistance of austenitic steels during the operation. The $\mathrm{Z}$ phase precipitates inside the grains in a finely dispersed form. In accordance with the Orowan mechanism, this provides an effective reduction and inhibition of free dislocation movement. The high thermodynamic stability of these precipitates results in a very slow increase in their size.

Microanalysis of chemical composition of precipitates

in Sanicro 25 steel after creep test carried out using scanning electron microscope with EDS detector

\begin{tabular}{|c|c|c|c|c|c|c|c|c|}
\hline \hline Element, Wt\% & $\mathbf{C}$ & $\mathbf{N}$ & $\mathbf{W}$ & $\mathbf{N b}$ & $\mathbf{T i}$ & $\mathbf{C r}$ & $\mathbf{N i}$ & $\mathbf{F e}$ \\
\hline $\mathrm{MX}$ & 9.09 & 6.91 & - & 21.19 & 62.86 & & - & \\
\hline $\mathrm{M}_{23} \mathrm{C}_{6}$, at the grain boundary & 6.95 & - & 10.93 & - & - & 44.07 & 14.72 & 23.43 \\
\hline $\mathrm{M}_{23} \mathrm{C}_{6}$, inside the grain & 6.26 & - & 34.22 & - & - & 15.97 & 13.72 & 29.83 \\
\hline
\end{tabular}
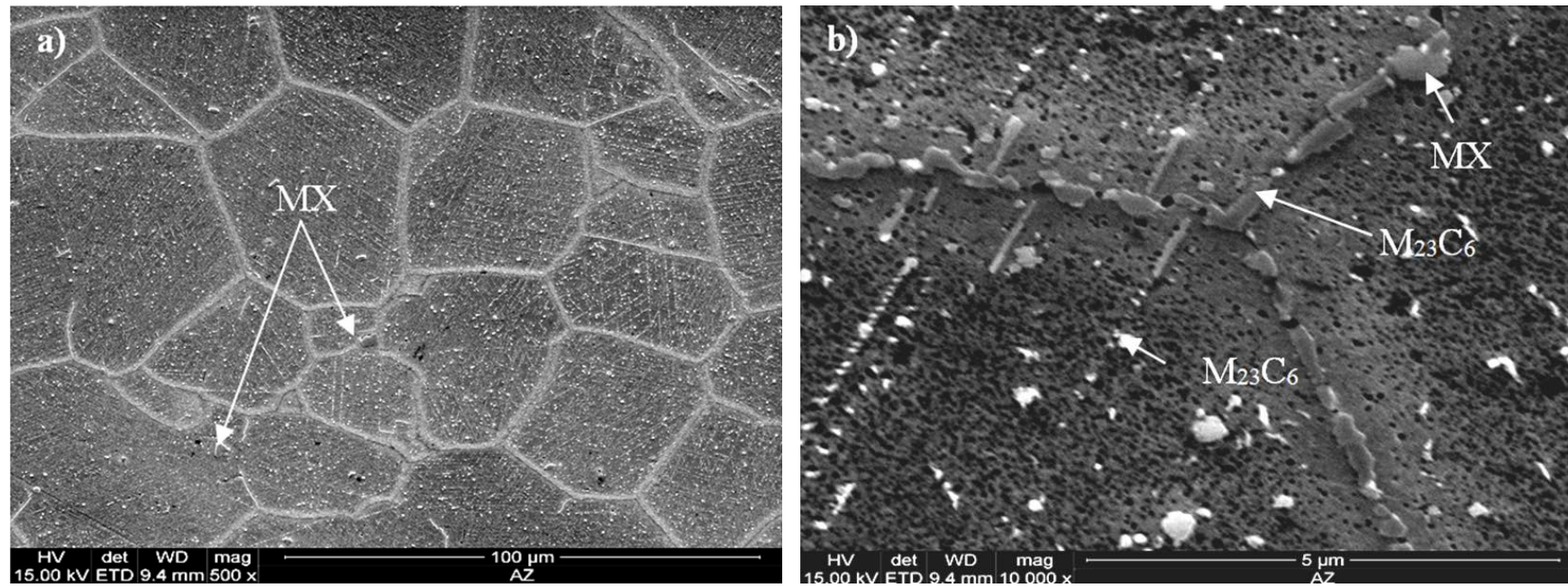

Fig. 6. Microstructure of Sanicro 25 steel after long-term exposure to temperature and stress $\left(675^{\circ} \mathrm{C} / 200 \mathrm{MPa} / 675 \mathrm{~h}\right)$ 

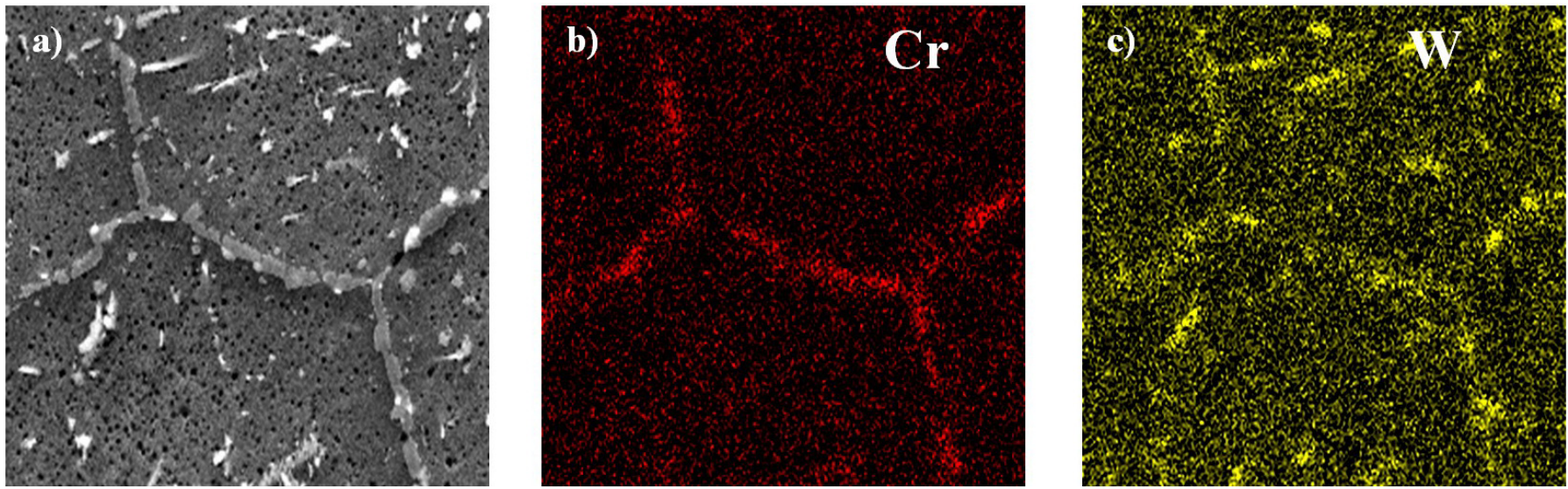

Fig. 7. Morphology of precipitates after creeping $\left(675^{\circ} \mathrm{C} / 200 \mathrm{MPa} / 675 \mathrm{~h}\right)$ with surface distribution of chromium b) and tungsten c) in Sanicro $25 \mathrm{steel}$
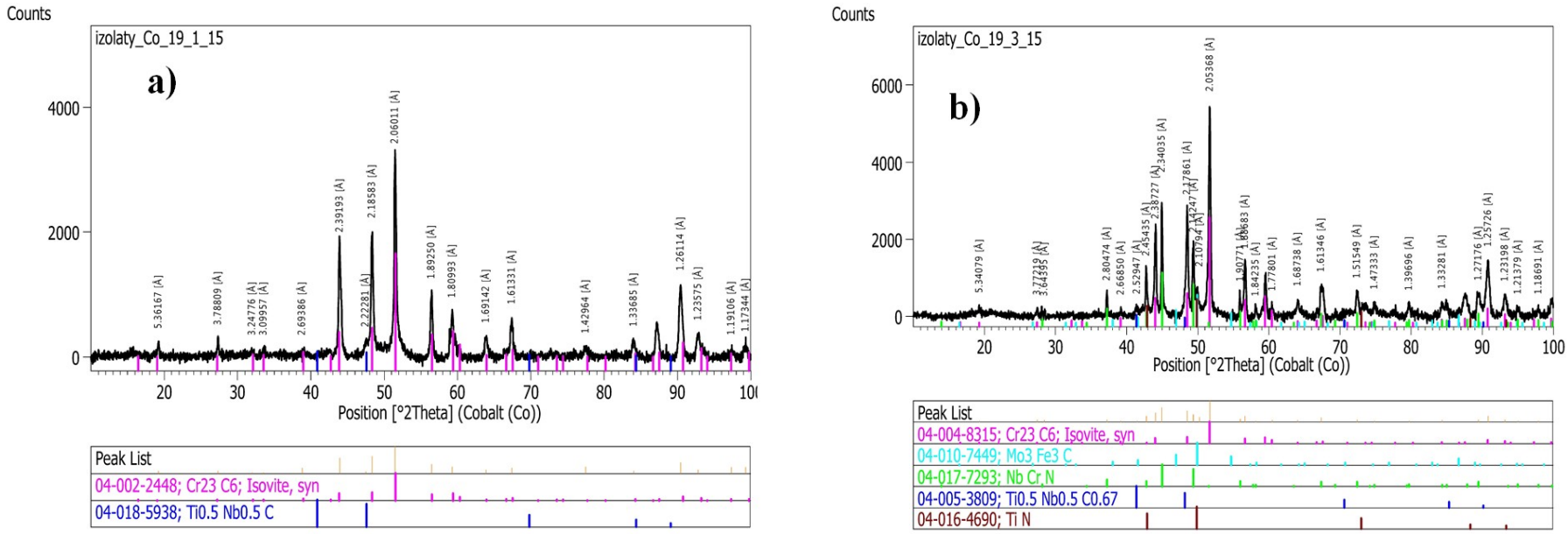

Fig. 8. Diffractogram of isolates extracted from the investigated materials after creep test: a) HR6W alloy, b) Sanicro 25 steel

\subsection{Hardness}

Hardness distribution over the cross-section of the investigated dissimilar welded joint is shown in Fig. 9. Hardness measurements suggest similar hardness of the investigated materials, which is about 180-190 HV10. In addition, hardness in the heat affected zone of both Sanicro 25 steel (HAZ1) and HR6W alloy (HAZ2) is approximately $10-15 \%$ higher than that in the basic material.

\subsection{Creep strength}

Creep tests of the parent material of Sanicro 25 steel, HR6W alloy and dissimilar welded joint made of them were carried out at $650^{\circ} \mathrm{C}, 675^{\circ} \mathrm{C}, 700^{\circ} \mathrm{C}, 725^{\circ} \mathrm{C}$ and $750^{\circ} \mathrm{C}$ at the stress of $200 \mathrm{MPa}$. Regardless of temperature, the rupture for the investigated welded joint took place in the parent material of HR6W alloy within the heat affected zone. The results of creep tests as $\log \mathrm{t}_{\mathrm{z}}=\mathrm{f}\left(\mathrm{T}_{\mathrm{b}}\right)$ at $\sigma_{\mathrm{b}}=$ const are shown in Figure 10.

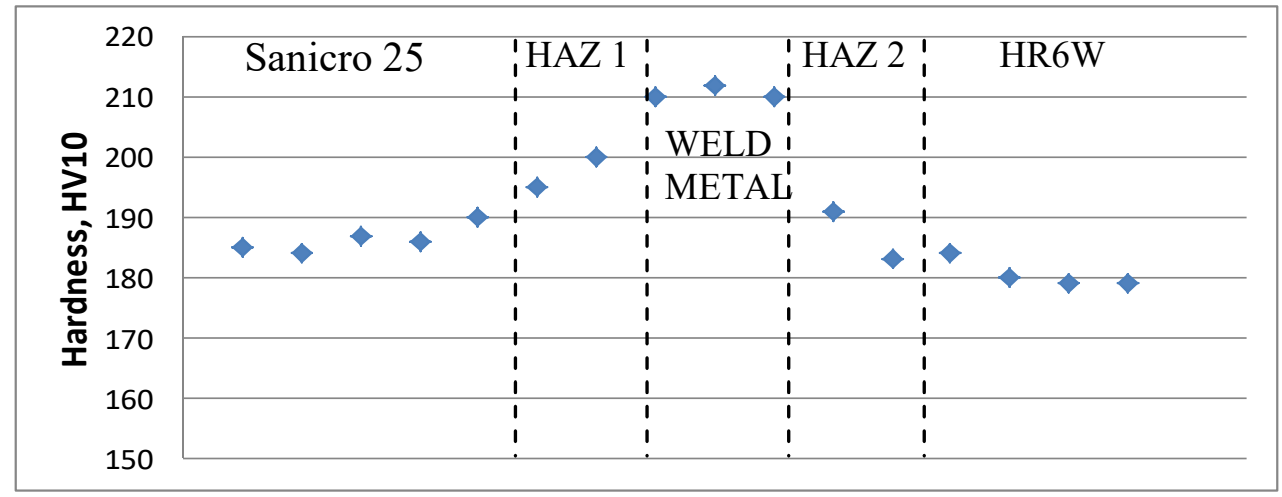

Fig. 9. Results of hardness measurements of Sanicro25/HR6W dissimilar welded joint steel in the as-received condition 


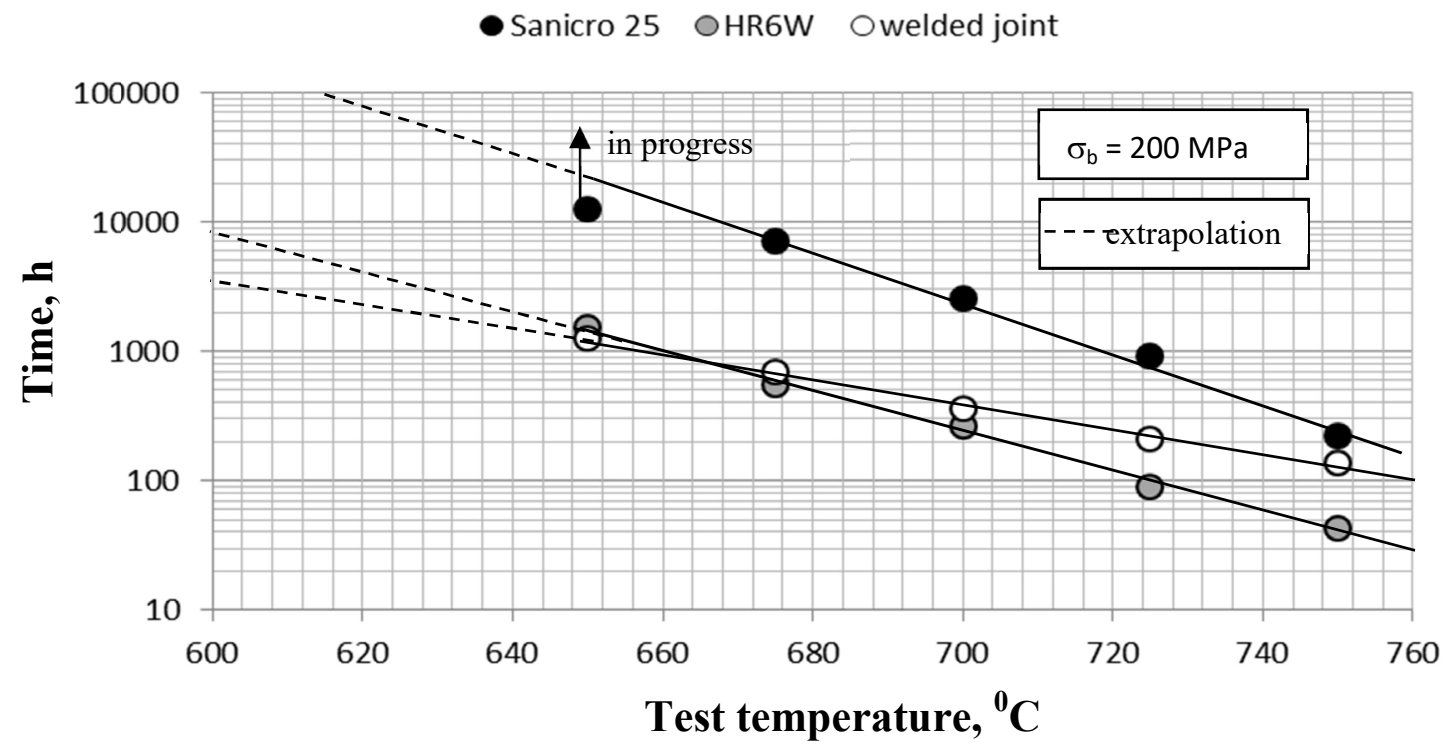

Fig. 10. Results of abridged creep tests

On the basis of the creep tests performed with the extrapolation method presented in section 3, the service life of the investigated materials and their welded joint was estimated. The service life characterises the ability to maintain the required fitness for use until the limit state when its further operation is not advisable has been achieved.

The obtained results of extrapolation based on completed creep tests are summarised in Table 7.

TABLE 7

Forecast service life of the investigated materials and their dissimilar welded joint

\begin{tabular}{|c|c|c|c|c|}
\hline \hline No. & Material & $\begin{array}{c}\text { Stress } \\
\text { Test stress } \\
\boldsymbol{\sigma}_{\boldsymbol{b}} \text {, [MPa] }\end{array}$ & $\begin{array}{c}\text { Assumed } \\
\text { operating } \\
\text { temperature T } \\
{\left[{ }^{\circ} \mathbf{C}\right]}\end{array}$ & $\begin{array}{c}\text { Estimated } \\
\text { service life, } \\
{[\mathbf{h}]}\end{array}$ \\
\hline 1 & Sanicro 25 & & & $>100,000 \mathrm{~h}$ \\
\cline { 1 - 2 } 2 & HR6W & \multirow{2}{*}{200} & 600 & $\sim 10,000 \mathrm{~h}$ \\
\cline { 1 - 2 } 3 & $\begin{array}{c}\text { HR6W/Sanicro25 } \\
\text { welded joint }\end{array}$ & & & $\sim 7000 \mathrm{~h}$ \\
\hline
\end{tabular}

\section{Summary}

This paper presents two grades of materials with austenitic structure (HR6W, Sanicro 25) for applications related to steam superheater coils in the modern power industry.

The observation of microstructure and identification of the existing types of precipitates in the investigated materials, both in the as-received condition and after creep test, allowed changes in the image of microstructure of the investigated materials to be described with particular consideration given to the areas where primary and secondary phases occur.
The principles for conducting the abridged creep tests at constant stress and variable temperature in the assessment of service life of the steels used for operation at elevated temperature were discussed.

The obtained results of creep tests for HR6W alloy and Sanicro 25 steel and their reference to literature data $[13,14]$ confirmed their required creep strength in the as-received condition. However, as might be expected, creep strength of the HR6W/Sanicro25 dissimilar welded joint is lower than that of the material characterised by lower creep strength, in this case of the base material of HR6W.

The extrapolation of the results of creep tests allowed the service life of both the investigated materials and the dissimilar welded joint to be determined provisionally. The strength of the investigated dissimilar welded joint is approximately $30 \%$ lower than that of the base material of HR6W.

The investigations presented in the work constitute the database of material characteristics of steels and alloys as well as welded joints made of them working under creep conditions, which are developed by the Institute for Ferrous Metallurgy [15-17]. The results of the investigations are used in the diagnostics of pressure components of power boilers as well as in modernisation and design of pressure components of steam boilers for the modern power industry.

\section{Acknowledgements}

The results in this publication were obtained as part of research co-financed by the National Science Centre under contract 2011/01/d/st8/07219 - Project: „Creep test application to model lifetime of materials for modern power generation industry". This publication was co-financed by the Ministry of Science and Higher Education of Poland as the statutory financial grant of the Faculty of Mechanical Engineering SUT. 


\section{REFERENCES}

[1] J. Brózda, Institute of Welding Bulletin 1, 41 (2004).

[2] J. Dobrzański, Open Access Library, Materials science interpretation of the life of steels for power plants, Gliwice 2011.

[3] A. Hernas, J. Dobrzański, J. Pasternak, S. Fudali, Characteristics of the new-generation materials for the power industry, Publishing House of the Silesian University of Technology, Gliwice 2015.

[4] A. Zieliński, J. Dobrzański, H. Purzyńska, G. Golański, Mater. Test. 57, 859-865 (2015).

[5] A. Zieliński, G. Golański, M. Sroka, Mater. Sci. Eng. A 682, 664672 (2017)

[6] A. Hernas, J. Dobrzański, Life-time and damage of boilers and steam turbines elements, Publishing House of the Silesian University of Technology, Gliwice, 2003.

[7] G. Golański, A. Zieliński, A. Zielińska-Lipiec, Materialwiss. Werkst. 46 (3), 248-255 (2015).

[8] P. Duda, Inverse estimation of the transient-state stress distribution in the power boiler pressure components, International Journal of Mechanical Sciences 107, 201-214 (2016).
[9] P. Duda, Ł. Felkowski, J. Dobrzański, An analysis of an incident during the renovation work of a power boiler superheater, Engineering Failure Analysis 57, 248-253 (2015).

[10] J. Kępa, G. Golański, A. Zieliński, A. Brodziak-Hyska, J. Vibroeng. 14 (1), 143-150 (2012).

[11] A. Zieliński, G. Golański, M. Sroka, Int. J. Pressure Vessels Piping 152, 1-6 (2017).

[12] J.P. Shingledecker, N.D. Evans, Int. J. Pressure Vessels Piping 87, 345-350 (2010).

[13] Vd TÜV Material data sheet 559/2 Supplement 09.2011.

[14] Vd TÜV Material data sheet 555, 09.2008.

[15] P. Duda., Ł. Felkowski, J. Dobrzański, H. Purzyńska, Modelling the strain and stress state under creep conditions in P91 steel, Materials at High Temperatures 33, 1, 85-93 (2016).

[16] A. Zieliński, M. Miczka, M. Sroka, Mater. Sci. Tech-Lond. (2016), doi:10.1080/02670836.2016.1150242 (in press).

[17] A. Zieliński, M. Miczka, B. Boryczko, M. Sroka, Arch. Civ. Mech. Eng. 4, 813-824 (2016). 